Passagens. Revista Internacional de História Política e Cultura Jurídica,

Rio de Janeiro: vol. 3, no.3, setembro-dezembro 2011, p. 432-464.

\title{
APONTAMENTOS PARA UMA HISTÓRIA DOS SISTEMAS PENAIS ${ }^{1}$ \\ APUNTES PARA UMA HISTORIA DE LOS SISTEMAS PENALES \\ NOTES ON THE HISTORY OF PENAL SYSTEMS \\ ÉLÉMENTS POUR UNE HISTOIRE DES SYSTÈMES PÉNAUX
}

DOI: $\underline{10.5533 / 1984-2503-20113305}$

Pedro Tórtima

\section{RESUMO}

O texto analisa a história dos sistemas penais na Europa e no Brasil, a partir da discussão sobre o quadro penal penitente que envolve as sociedades ocidentais. Aborda o surgimento das casas de correção e de detenção no Brasil, no século XIX, à luz das referências ao pensamento penitenciário europeu e à presença da escravidão.

Palavras-chave: sistemas penais, casas de correção, Europa, Brasil.

\section{RESUMEN}

El texto analiza la historia de los sistemas penales en Europa y en Brasil, a partir de la discusión sobre el panorama penal penitente que envuelve las sociedades occidentales. Aborda el surgimiento de las casas de corrección y de detención en Brasil, en el siglo XIX, a la luz de las referencias al pensamiento penitenciario europeo y ante la esclavitud.

Palabras-clave: sistemas penales, casas de corrección, Europa, Brasil.

\section{ABSTRACT}

The text analyses the history of penal systems in Europe and Brazil beginning with a discussion on the penitent penal position in Western societies. It tackles the emergence of

\footnotetext{
1 Originalmente, este trabalho de autoria de Pedro Tórtima, tendo como participantes Alexandre Fragoso, Eduardo Schneider, Erisson J. de Carvalho, Darcon P. de Araújo, Fabíola O. Strong, Felipe V. de Souza, Mônica E. de Lima, Paulo Cruz da Silva Jr., Sandra J. Villaverde. Todos integram a equipe de pesquisadores (Mestrado em Direito/UCAM); Gabriela Gonçalves, formada em História pela UERJ foi responsável pela pesquisa de fontes primárias do cotidiano prisional, sobretudo no século XIX no Rio de Janeiro.
} 
Passagens. Revista Internacional de História Política e Cultura Jurídica,

Rio de Janeiro: vol. 3, no.3, setembro-dezembro 2011, p. 432-464.

correctional facilities and detention houses in nineteenth-century Brazil in light of European penitentiary thought and the presence of slavery.

Keywords: penal systems, correctional facilities, Europe, Brazil.

\title{
RÉSUMÉ
}

Ce texte analyse l'histoire des systèmes pénaux en Europe et au Brésil, à partir d'une discussion sur le cadre pénal pénitent des sociétés occidentales. Nous aborderons l'apparition des maisons de correction et de détention dans le Brésil du XIX ${ }^{\mathbb{e}}$ siècle, à la lumière de références à la pensée pénitentiaire européenne et à la présence de l'esclavage. Mots-clés : systèmes pénaux ; maisons de correction ; Europe ; Brésil.

\section{Parte I}

\section{A intimidade do encarceramento: os primeiros passos - e os subterrâneos da miséria cotidiana no interior do ser humano}

\begin{abstract}
Se me perguntassem: O que poderia ser feito para melhorar o regime penitenciário? Responderia: Nada! Porque não é possível melhorar uma prisão. Salvo algumas pequenas reformas sem importância, não há absolutamente nada o que fazer, senão demoli-las. (Piotr Alexander Kropotkin ${ }^{2}$ ).
\end{abstract}

A iniciativa de esboçar algumas palavras que sirvam de subsídio para uma tentativa mais sistemática, a fim de abordar questões controversas, muitas vezes nodais, advêm da necessidade de melhor discutir o quadro penal penitente envolvendo a sociedade, bem como esse conjunto social em si.

Michel Foucault (1926-1984) admite que a prisão, desde sempre, esteve intimamente ligada a um projeto de transformação dos indivíduos e que passou a ser vista como um depósito de criminosos; depósito, cujos inconvenientes se teriam constatado por seu

\footnotetext{
${ }^{2}$ Militante anarquista e geógrafo russo, Piotr A. Kroptkin (1842-1921) foi, desde a década de 1870 até sua morte, em Moscou na União Soviética, destacado ativista e teórico do movimento libertário-internacionalista europeu. O texto que acabamos de reproduzir foi extraído de uma conferência que pronunciou para trabalhadores em Paris, naquele agitado dezembro de 1877 e, que mais tarde, foi convertido em divulgada brochura, sob o título de "As prisões".
} 
Passagens. Revista Internacional de História Política e Cultura Jurídica,

Rio de Janeiro: vol. 3, no.3, setembro-dezembro 2011, p. 432-464.

funcionamento, de tal forma que se teria dito ser necessário reformar as prisões, fazendo delas um instrumento de modificação dos indivíduos...

Mas, como observa o filósofo francês, em certa medida tal afirmação é uma inverdade: os textos, os programas, as declarações de intenção estavam ali para demonstrar. E sublinha: desde o princípio, “(...) a prisão devia ser um instrumento tão aperfeiçoado quanto a escola, a caserna ou o hospital e agir com precisão sobre os indivíduos" 3 .

$\mathrm{Na}$ verdade, o controle prisional é parte integrante do universo que aciona, permanentemente, mecanismos de manipulação no seio da sociedade. A prisão afunila (e expõe) aspectos e formas intestinas do controle institucional.

A pena carcerária e penitente é, e sempre foi a expressão mais clara do forte direito de castigar. Aí, não se pensa absolutamente na regeneração, a não ser de forma discursiva e francamente religiosa ${ }^{4}$.

A prisão, o cárcere, a galé ${ }^{5}$, o castigo físico, o exílio, a multa, a execução, desnudam e até desvendam o quadro da guerra social que sempre se anuncia.

O próprio Direito Penal ${ }^{6}$ acompanha essa lógica: os alemães Georg Rusche e Otto Kirchheimer identificavam, por exemplo, claramente, a crescente intensificação dos conflitos sociais $^{7}$, na região dos Flandres, na Toscana e no norte da Alemanha, que sinalizaram a transição para o capitalismo - entre os séculos XIV e XV - levando à criação de leis

\footnotetext{
${ }^{3}$ Foucault, Michel (1985). Microfísica do poder, 5 ed, Rio de Janeiro: Graal, p. 131.

${ }^{4}$ Numa matéria sobre a Casa de Correção do Rio de Janeiro, escrita na Revista Popular, da Corte, de jul-set de 1861, do ano de 1861, à p. 45, o autor, Fernando de Pina, é textual: Nenhum pensamento regenerador, nenhuma ideia de melhoramento, de elevação moral dos desgraçados que se haviam alistado no funesto exercito do crime, passava pela mente dos legisladores - que nas prisões só viam lugares de expiação e de segurança, eretos contra os malfeitores .Aproximadamente um século depois, o criminalista e penalista brasileiro Augusto Frederico Gaffrèe Thompson (1931-2007), referindo-se à questão penitenciária, frisou que a mesma não tem solução "em si", porque não se trata de um problema "em si". Mas, adianta o jurista baiano, parte integrante de outro maior. Ou seja, a questão criminal nada mais é que mero elemento de outro elemento bem mais amplo - o das estruturas sócio-político-econômicas. Neste sentido, esclarece Thompson, sem mexer nessas estruturas coisa alguma vai alterar-se: tanto na área criminal, como ainda menos na penitenciária. (ver Thompson, A. (2002). A questão penitenciária, 5 ed, Rio de Janeiro: Forense, p. 110).

${ }^{5}$ Era o trabalho compulsório nas galeras, praticado pelos escravos bem como pelos forçados, ou seja, pelos condenados. Tanto a mão-de-obra escrava, como aquela composta pelos condenados tinha como vantagem a gratuidade do labor... O trabalho principal era o duro e pesado remo.

${ }^{6}$ O Direito Canônico, por exemplo, fruto de uma extensa série normativa medieval de leis e decretos, justificava a prática prisional. De fato, em 1234, 12981313 e 1317, esboçava-se o "corpo de direito canônico" que em 1497 passa a ter sua "redação" escrita aparentemente conclusiva. Mas só aparentemente.

${ }^{7}$ Sobre o sistema prisional e repressivo europeu, em pleno feudalismo, ver de Duby, George (1990). Senhores e camponeses, São Paulo: Martins Fontes. No capitulo final, existem algumas referências importantes.
} 
Passagens. Revista Internacional de História Política e Cultura Jurídica, Rio de Janeiro: vol. 3, no.3, setembro-dezembro 2011, p. 432-464.

criminais inflexíveis, dirigidas contra as classes subalternas ${ }^{8}$ - a prisão estava entre essas leis.

Realmente, o encarceramento em tempos feudais ou pouco depois era mais limitado às fortalezas e as penas do degredo que principiavam e mesmo as galés cumpriam ou ajudavam a cumprir essa função. O enforcamento e outras execuções do gênero igualmente.

Os suplícios e, até mesmo, a maior frequência da pena capital começam, aos poucos, a dar lugar às práticas repressoras de maior "racionalidade" e sutil pragmatismo confirmando, no entanto, que a maior economia desse velho castigo verdugo não denunciava que ele tivesse sido extinto. Foucault observa isso.

Tudo indica, diz ele, realmente, que a partir do XIX, o suplicio físico é - pelo menos escamoteado ${ }^{9}$ : exclui-se (em parte) do castigo a encenação da dor. Na verdade, penetra-se na época da sobriedade punitiva ${ }^{10}$.

Neste sentido, a prisão tende a substituir, num processo de há muito gestado, as formas de punição mais próximas do suplício e da pena de morte. Rusche e Kirchheimer chegam a afirmar que em fins do XVI, os métodos de punição começaram a sofrer uma mudança gradual e profunda ${ }^{11}$. E que estas mudanças não resultam de (...)

(...) considerações humanitárias, mas de um certo desenvolvimento econômico que revelava o valor potencial de uma massa de material humano completamente à disposição das autoridades $O$ criminoso podia não apenas evitar as galés pelo alistamento, quanto recebia um tratamento especial se cometesse um crime enquanto servisse o exército ${ }^{12}$.

Realmente, voltando ainda ao Renascimento, o XVI europeu, especialmente nos países envolvidos em vigorosas atividades mercantes e mercantis onde o fluxo e refluxo de riquezas implicavam no rígido controle da mão de obra, na escravidão, nas galés, na deportação e servidão penal, todos esses trabalhos forçados passaram a fazer parte do cotidiano social e as modalidades da pena já se anunciavam de outra forma.

O surgimento das Casas de Correção, criadas com o propósito de "limpar as cidades de vagabundos e mendigos" fez parte de um projeto, inicialmente, da urbe londrina que, às

\footnotetext{
${ }^{8}$ Rusche, G \& Kirchheimer, O. (1999). Punição e estrutura social, Rio de Janeiro: Freitas Bastos, p. 28.

${ }^{9}$ Foucault, M. (1983). Vigiar e punir, nascimento da prisão, 2ª . Edição, Petrópolis: Vozes, p. 18.

${ }^{10}$ Ibidem, p. 18-19.

${ }^{11}$ Rusche, G. \& Kirchheimer, O. (1999). Op. cit., p. 39.

12 Ibidem.
} 
Passagens. Revista Internacional de História Política e Cultura Jurídica, Rio de Janeiro: vol. 3, no.3, setembro-dezembro 2011, p. 432-464.

pressas, se travestiu com modernas vestes ${ }^{13}$. E em 1555, dentro desse pioneirismo carcerário, outro caldo prisional se manifestou: desta vez nos Países Baixos ${ }^{14}$. Os bagnes ${ }^{15}$ já eram considerados fora de uso e de nenhuma utilidade carcerária prática e concreta.

Tratava-se (as casas de correção), como o titulo chega a sugerir, de um estabelecimento com vistas a um grau de aprisionamento de outra ordem. Em palavras diferentes: aqui, o importante não era somente encarcerar, mas corrigir. E o Estado corrige, as instituições oficiais corrigem. A Igreja e a escola, também, a sua maneira, corrigem. $\mathrm{Na}$ verdade, fazem parte do mesmo complexo institucional, dos mesmos aparelhos estatais: a Polícia, as Igrejas, a rede pública escolar e a rede privada, o ensino superior, bem como a Justiça, toda a estrutura hospitalar, o sanitarismo e os diversos meios de divulgação que se encarregam de transmitir o discurso da classe dominante.

Amsterdã foi mais além. Segundo o sociólogo Zygmunt Bauman, os idealizadores e promotores da Casa de Correção, inaugurada nessa (próspera) cidade, no início do século XVII, tinham em seus planos produzir homens saudáveis, moderados no comer, acostumados ao trabalho, com vontade de ter um bom emprego, capazes do próprio sustento e tementes a Deus ${ }^{16}$.

Mas, na prática, essa "reabilitação" que antes compreendia intensa e bem variada atividade artesanal, acabou se limitando à raspagem de pau Brasil ${ }^{17}$. Ao que tudo indicava, esta atividade passou a tomar proporções de real castigo, face à dureza com que foi encaminhada provavelmente para atender as demandas desse comércio.

\footnotetext{
${ }^{13} \mathrm{Na}$ Inglaterra, no Castelo de Bridewell, podemos identificar uma das primeiras instituições de controle da mendicância (séc. XVI) e que, posteriormente, serviu de modelo para as muitas instituições do gênero por toda a Europa.

${ }^{14}$ Em fins do século XVI, ou mais precisamente em 1595, inspirada nos penitenciários do Santo Ofício da Inquisição, a Holanda constrói a primeira penitenciária masculina e dois anos mais tarde, em 1597, constrói outra, esta feminina. Ambas em Amsterdã. De fato, o surgimento da prisão está intimamente ligado com a fantástica escalada da acumulação do capital. Rusche e Kirchheimer insistem justamente nisso: os métodos de punição começaram a sofrer uma mudança gradual e profunda em fins do século XVI. Ver o cap. III ("Mercantilismo e Surgimento da Prisão") do livro aqui citado desses mesmos autores.

${ }_{5}$ Os bagnes...- uma alusão às antigas "casas de banho", instaladas, primeiramente, em Constantinopla eram, ao que consta, um "instrumento" para aprisionar as mulheres...(e depois os escravos ditos cristãos). Até a primeira metade do XVIII, uma das penas-crimes era a das galeras. Mas o "progresso" nas artes náuticas fez algumas substituições. Isto é, a partir de 1748, os progressos da marinha à vela forçaram o abandono da canoagem - os "galés" foram internados em certos lugares dos portos de guerra: que receberam o nome de "banhos". De qualquer forma, essas "prisões" tinham como objetivo o absoluto controle da população marginal (ver a esse respeito, o trabalho de Jacques Valette, Le bagne de Rochefort, 1815-1852 In: Perrot, Michelle (1980). L'Impossible Prison; recherches sur le système pénitentiaire au XIX siècle, Paris: Seuil).

16 Ver Bauman, Z. (1999). Globalização, as consequências humanas, Rio de Janeiro: J. Zahar, p. 118.

17 Ibidem, p. 118.
} 
Passagens. Revista Internacional de História Política e Cultura Jurídica,

Rio de Janeiro: vol. 3, no.3, setembro-dezembro 2011, p. 432-464.

Amsterdã era (e ainda é) um porto de intensa atividade comercial internacional. E, naquele século, a poderosa Companhia das Índias Ocidentais, desempenhava um papel centralizador nas trocas, fazendo parte dos Países Baixos ${ }^{18}$. Realmente, na primeira metade do XVII, essa cidade havia se convertido no principal centro comercial europeu.

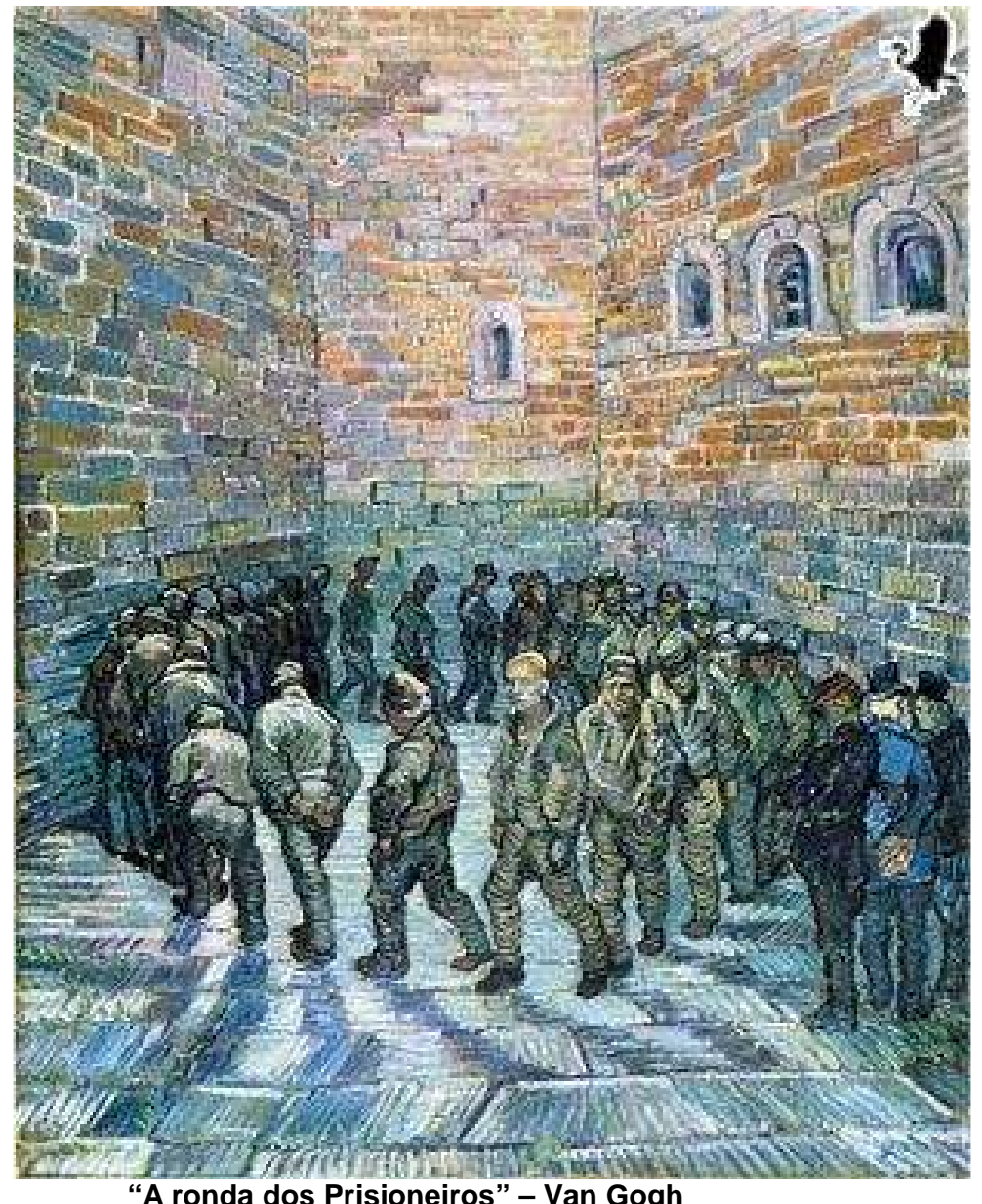

Numa formação social, aonde a escassez de terras, chegava a ser surpreendente, sua agricultura recebeu grande estímulo de capitais. Explica-se o contexto, pela excepcional expansão mercadora internacional dessa rica e operosa burguesia, articulada pela ideologia calvinista ${ }^{19}$.

\footnotetext{
${ }^{18}$ Compunham os Países Baixos, no século XVI, em seu total, dezessete províncias. As mais importantes eram: o território da Bélgica atual, pequena parte da França, Luxemburgo e Holanda.

${ }_{19}$ Dario Melossi e Massimo Pavari consideram - em parte reportando-se a Karl Marx, 1818-1883, (em O Capital, v. I) - que já se prenunciavam na Holanda, fortes vestígios de práticas capitalistas típicas do séc. XVII.
} 
Passagens. Revista Internacional de História Política e Cultura Jurídica, Rio de Janeiro: vol. 3, no.3, setembro-dezembro 2011, p. 432-464.

De outro lado, à par das atividades comercial e financeira, desenvolvia-se a forte indústria da construção naval, o avançado artesanato de tapetes, a fabricação de fios e de chocolate, a produção de licores, de peixe salgado, de artefatos de couro e de sofisticados produtos de madeira, etc.

A cidade passou, também, a receber muitos refugiados estrangeiros e, nessa esteira, a contribuição de muitos deles, no que diz respeito à qualidade da mão de obra. Um exemplo era a arte do corte do diamante. Diante disso, a burguesia holandesa, naturalmente, pressentia que esta cidade portuária, em face de tal prosperidade, poderia sofrer alterações em sua ordem institucional.

Foi nesse contexto, que surgiu essa Casa de Correção e foi, também, nesse próprio contexto da expansão mercantil que ela assumiu proporções de outro vulto. O temor de classe estava aí embutido.

Segundo Rusche e Kirchheimer, o exemplo de Amsterdã foi estudado e amplamente seguido em toda Europa, particularmente nos países de língua alemã (Bremen, Lübeck, Hamburgo, Dansig, Lüneburg, Bern, Basel, Freiburg, etc.).

Contudo, as Casas de Correção, em suas formas mais tradicionais, passaram a perder o seu antigo vigor. Uma mudança se verificou bem sutil, mas que revelava os novos tempos - em que o quadro social do mundo estava mais e mais composto de flagelados, prostitutas, ladrões e marginalizados - previamente sentenciados com penas longas, legadas pela miséria. A guerra dos mercados estava acirrada, prenunciando outra etapa do desenvolvimento social.

A antiga estrutura daquela instituição não conseguia dar conta, em termos de uma real política repressora, da segurança exigida pelo conjunto das classes dominantes. Talvez tenham sido essas as razões pelas quais outros caminhos foram procurados para "solucionar" o problema dos pobres, desvalidos, necessitados, prostitutas, mendigos ditos profissionais, desempregados, vagabundos ou assim considerados e loucos, dementes...

Criaram-se, finalmente, por essa razão, sobretudo na França, os Hôpitaux Généraux. O primeiro Hôpital surgido em Paris foi no ano de 1656. Os internos do sexo masculino eram

Consideram estes autores que a chamada casa de trabalho atingia, no período das origens do capitalismo, a sua forma mais desenvolvida. Argumentam, ainda, Melossi e Pavari que a criação desta modalidade de segregação punitiva atendia mais a uma demanda relacionada ao desenvolvimento global da sociedade capitalista do que à genialidade de uma só pessoa. (Ver Melossi, Dario e Pavarinni, Massimo (2006). Cárcere e fábrica: as origens do sistema penitenciário; séculos XVI - XIX, Rio de Janeiro: Revan, ICC, p. 36.) 
Passagens. Revista Internacional de História Política e Cultura Jurídica, Rio de Janeiro: vol. 3, no.3, setembro-dezembro 2011, p. 432-464.

utilizados principalmente nas monótonas práticas da raspagem de madeiras, semelhante às empregadas nas oficinas prisionais de Amsterdã. Era um esforço que implicava uma resistência especial e os prisioneiros ou internos, trabalhavam aos pares. $\mathrm{O}$ trabalho rendia mais: um vigiava o outro - numa atividade incrivelmente monótona e repetitiva.

No século $\mathrm{XV}$, nos albores da modernidade européia, o trabalho compulsório não desapareceu, persistiu. A acumulação de riquezas assim o exigia. Não se tratava propriamente do trabalho escravo - ainda que existisse - mas do braço forçado "marginal" que, juridicamente, não deixava de ser servil e, na prática, compulsório.

O trabalho nas galés tomou proporções diferentes e de maior vulto. Em meados do $\mathrm{XVI}$, por exemplo, os grandes Estados da Europa, consideraram essa prática punitiva preferível à pena de morte aplicada, comumente, aos marginais.

Organizavam-se caçadas metódicas à população vagabunda destinada a preencher na qualidade de forçados - um estratégico espaço de trabalho, agora constituído por uma mão-de-obra ou muito barata ou mesmo escrava ${ }^{20}$.

Segundo Rusche e Kirchheimer, em fins de 1573, Nuremberg ${ }^{21}$ forneceu cerca de quarenta homens recrutados dentre ladrões comuns, vagabundos e assassinos para essas empresas.

Algumas coisas, pelo menos, ficavam claras: o espaço dispendioso (arquitetural e funcional) do cárcere parecia bastante equacionado. As galés funcionaram, aos poucos, como um espelho de prisão da modernidade mercantilista.

Rusche e Kirchheimer, uns dos poucos autores sobre o assunto, à vista, lembram que até mesmo na famosa Encyclopedie, dirigida por Denis Diderot (1713-1784), existiam defensores do trabalho forçado. O autor do artigo "Galérien" chegou a afirmar: " $A$ introdução

\footnotetext{
${ }^{20} \mathrm{Na}$ França do mercantilista e todo poderoso ministro Jean-Baptiste Colbert (1665-1683), o governo fez forte pressão sobre os tribunais para conseguir prisioneiros em número suficiente com o propósito de manter as tripulações completas. E o Promotor Público do Parlement de Paris é notificado, por uma carta, com o objetivo claro de garantir a "presença" de um grande número de prisioneiros capazes de servirem nas galés na Concergeirie. O mercantilismo na França, até mesmo por razões intrínsecas de sua economia, fugia inteiramente aos padrões "mercantes" do restante da Europa. Fundamentalmente, a prática mercantil do Estado francês, dava prioridade à agricultura, isto é, incentivando esta atividade, se opunha a que os produtos agrícolas fossem pagos em ouro no comércio internacional. Em outras palavras ainda: era uma forma de não depender da exportação de seus produtos primários, fazendo crescer o mercado consumidor e a real produção interna. Um interessante estudo sobre a função das galés e da mão-de-obra ali empregada está em G. Rusche e O. Kirchheimer, Punição e estrutura social (cap. IV). Ver, também o cap. II de Zaffaroni, E. Raúl (2007). O inimigo no Direito Penal, Rio de Janeiro: Revan. O autor faz uma bela analise do poder punitivo da Revolução Mercantil.

${ }^{21}$ Muitas cidades alemães do sul-ocidental eram excepcionalmente ricas: entre elas, Nuremberg, Augsburg, Ulm e Estrasburg podiam, à época, ser consideradas os centros comerciantes europeus dos mais prósperos.
} 
Passagens. Revista Internacional de História Política e Cultura Jurídica, Rio de Janeiro: vol. 3, no.3, setembro-dezembro 2011, p. 432-464.

da escravidão nas galés foi uma medida inteligente. Ela mantém os homens, cujos crimes haviam sido exilados ou resgata-os da pena capital, a serviço do Estado sem perigo para a sociedade. Mais ainda, ela está de acordo com os pressupostos humanitários"22.

De qualquer forma, o trabalho nas galés teria que diminuir no XVIII e, de fato, diminuiu. Não por razões (ou não tanto por razões) humanitárias, mas pelos avanços técnicos que a arte de navegação começava a propiciar.

Em nível do contexto internacional, o mercado do XVI começava a se transformar: de um lado, ele "buscava" suas riquezas nos recantos do Mediterrâneo, na África, na Ásia e na América. Mas, de outro, o capital era "gerado" na própria Europa. Os Fugger, banqueiros e comerciantes bávaros de Augsburg eram, por exemplo, igualmente, donos de minas. Em suas mãos, também estavam as minas do Tirol e da Hungria.

Além de serem grandes arrendatários particulares, esses financistas emprestaram grandes somas ao rei da Espanha, Carlos de Habsburgo e, graças a esse dinheiro, o rei pôde subornar os príncipes eleitores e assegurar sua "escolha" como imperador da Alemanha, em 1519, com o nome de Carlos V (1500-1558). O caráter "sem fronteiras" do capital mercantil, já se fazia evidente.

Em mãos de Carlos V concentrou-se um enorme Estado, que incluía a "metalista" Espanha, com suas possessões italianas (Itália meridional e Sicília), as colônias americanas, o Império Germânico e, por fim, já no XVII, os Países Baixos. Dizia-se a respeito do soberano que, em seus domínios, nunca o Sol se punha ${ }^{23}$.

\footnotetext{
${ }^{22}$ Ver Rusche e Kirchheimer (1999), Op. cit., p. 8.

${ }^{23}$ Sobre o sistema penal europeu-feudal e o mundo mercantil que acrescentava outros elementos ideológicos a essa realidade política-jurídica da antiguidade, ver de Eugênio R. Zaffaroni, Nilo Batista, Alejandro Alagia e Alejandro Stokar, importante análise em: Direito penal brasileiro-l, 2 ed. Rio de Janeiro: Editora Revan, 2003, pp 383-394. De particular interesse é analise sobre a Inquisição e poder punitivo mercantilista - argumentam os autores que, quando o conflito deixou de ser lesão contra a vítima e passou a significar delito contra $o$ soberano, ou seja, quando sua essência real de lesão a um ser humano converteu-se em ofensa ao senhor, desvinculou-se da própria lesão e foi subjetivando como inimizade para com o soberano.

Pode-se depreender das palavras acima e da análise que aí se encerra que: numa primeira etapa do conflito, os pressupostos de um conflito social não estavam evidentes, mas tão logo o Poder passou a estar em questão, à reação se manifestou de forma radical.
} 
Passagens. Revista Internacional de História Política e Cultura Jurídica, Rio de Janeiro: vol. 3, no.3, setembro-dezembro 2011, p. 432-464.

\section{A deportação ultramarina, os degredados e as colônias penais: contradições dentro de um nascente e "promissor" capitalismo.}

Dentro da política mercantilista que prenunciava os primeiros "sintomas" ou mesmo um esboço do processo de acumulação capitalista, verifica-se nas formações sociais européias - voltadas para o comércio ultramarino - a utilização da força de trabalho de condenados: fossem proscritos-forçados, fossem escravos apresados derivados da prática colonialista.

A deportação surgiu, dentro da política do ultramar, como uma forma de preencher o "vazio", talvez étnico, do colonizador europeu.

De fato, e o historiador Ronaldo Vainfas parece ter bem compreendido: a principal função do degredado era ocupar um espaço na colônia recém-descoberta.

Sem contar que o degredo, por si mesmo, já constituía uma pena, um castigo - previsto para vários delitos da justiça secular, eclesiástica e inquisitorial.

Não podemos esquecer que degredar deriva de degradar, isto é diminuir de grau, rebaixar, argumenta Vainfas. Na prática, era a pena equivalente ao desterro ou aos trabalhos forçados que beneficiavam o Estado Absolutista ${ }^{24}$. Estado esse, que já despontava no conjunto social europeu.

A Inglaterra parece ter sido um dos primeiros países a introduzir a deportação como prática sistematizada excludente de criminosos ${ }^{25}$. De fato, o chamado Vagrancy Act em 1597, legalizou a deportação das "classes criminosas" para suas colônias.

De uma maneira geral, essas colônias tinham uma extensão geográfica bem superior à metrópole - o que levava as autoridades desta última a ter como estratégia, deslocar todo o peso de sua ação repressiva-colonizadora sobre a população nativa, numa "comunhão" com aqueles excluídos e proscritos sociais.

\footnotetext{
${ }^{24}$ Vainfas, Ronaldo (org) (2000). Dicionário do Brasil colonial (1500-1805), Rio de Janeiro: Objetiva, p. 180. Segundo Vieira Ferreira, nas relações da metrópole portuguesa com suas colônias, vigoravam as inflexíveis determinações das Ordenações do Reino. A primeira delas - as Afonsinas (1446), foram substituídas pelas Manuelinas em 1521 e, finalmente, pelas Filipinas em 1595. Mostra Ferreira aí, que o degredo (presentes a todas) consistia na proibição de entrar em certo lugar indicado ou na de sair do lugar indicado para cumprimento da pena ou na obrigação de servir nas galés do Estado (Ferreira, Vieira (1948). "O degredo nas ordenações do Reino e os degredados vindos com Pedro Álvares Cabral", In Revista do Instituto Histórico e Geográfico Brasileiro, v. 200, jul-set., p. 127. No caso do Brasil, por exemplo, o expediente utilizado pelos portugueses para "reconhecer" as terras e gentes do Brasil, além de "fabricar" os primeiros intérpretes, funcionava de modo a exercer uma política de povoamento (Apud Vainfas Ronaldo, p. 181).

${ }^{25}$ Rusche, G. \& Kirchheimer, O. (1999). Op. cit., p. 83.
} 
Passagens. Revista Internacional de História Política e Cultura Jurídica,

Rio de Janeiro: vol. 3, no.3, setembro-dezembro 2011, p. 432-464.

Ocorre, no entanto, que nem tudo é perfeitamente linear na lógica desenfreada do sistema de concorrência. No caso da Inglaterra, a prática da deportação passou a apresentar inconvenientes para aquele sistema colonial ${ }^{26}$. Chegou mesmo a ser, formalmente, condenada: os interesses metropolitas dominantes necessitavam, com urgência, de uma mão-de-obra "doméstica" barata. A indústria dava sutilmente os seus primeiros passos e as relações de produção do frio sistema, teciam as malhas (fortes) da engrenagem que prenunciava a chegada do capitalismo.

Mas com a introdução da escravidão africana nas últimas décadas do XVII, como observam Rusche e Kirchhheimer, as condições dos servos coloniais brancos começaram a deteriorar. A partir de 1635, traficantes de escravos negros ainda ganhavam um bônus, e a difusão do sistema de plantation fez crescer a demanda do trabalho servil ${ }^{27}$.

Do ponto de vista estritamente jurídico: a única diferença entre os condenados deportados e os escravos africanos, era que os primeiros estavam detidos por um período limitado de tempo, após o qual eram livres ${ }^{28}$ - ainda que debaixo de uma eterna condenação social.

A modernização do sistema prisional-penitenciário, não adveio, certamente, de um espírito iluminado e isolado. E sim de exigências maiores estabelecidas por um conjunto social: que do XVIII ao princípio do XX, teve uma "curiosa" trajetória.

\footnotetext{
${ }^{26} \mathrm{Em}$ Portugal, especialmente nos séculos XVIII e XIX, montou parte de seu sistema colonial, fortemente controlador, lançando mão de bem estudados estabelecimentos presidiários-cárceres. Só em Angola, na África, existiam cerca de dez verdadeiras fortalezas. Eram conhecidos os seguintes presídios: o de Ambaca, o de Caconda, o de Cambambe, o de Massangano, o de Muxima, o de Novo Redondo, o de Pedras de Encoge, o de Pedras de Pungo Andongo e muitos outros, geralmente construídos antes e em fins do séc.XVIII. Não eram apenas fortalezas, com objetivos militares, tampouco penitenciárias (como hoje se poderia imaginar), mas "postos" avançados com funções de toda uma estratégia colonial "ocupacional" de território. Em volta do edifício principal, existiam vilarejos, criações e plantações. Dentro do presídio havia toda uma população composta de soldados, escravos, trabalhadores comuns, funcionários e mulheres. As penitenciárias recebiam, igualmente degredados. E eles chegavam não somente de outras colônias, como também da própria metrópole. Muito interessante é, a respeito dos mecanismos acionados pelo centro metropolitano, o trabalho de Neder, Gizlene (2000). Iluminismo juídico-penal luso-brasileiro: obediência e submissão, Rio de Janeiro: Freitas Bastos/ICC.

${ }_{27}$ Ibidem, p. 86.

${ }^{28}$ Ibidem.
} 
Passagens. Revista Internacional de História Política e Cultura Jurídica, Rio de Janeiro: vol. 3, no.3, setembro-dezembro 2011, p. 432-464.

\section{Parte II}

\section{A disciplina assume novos e arrogantes ares - de modernidade e higiene.}

Atendendo a esses mesmos reclamos modernizantes, ancorados invariavelmente no pensamento conservador dominante, as penitenciárias projetadas e construídas a partir do séc. XVIII, introduzem um elemento novo: o trabalho, o "dignificante" trabalho dos presos, torna-se um "slogan". Portanto, o trabalho é um imperativo econômico e quem não trabalha não come. Na Bélgica, pelo menos, na penitenciária de Gand, construída em 1775, foi assim. A burguesia não admite, nunca admitiu momentos improdutivos, mesmo na reclusão dos excluídos da sociedade.

Fica muito claro que, a pena continua e permanece sendo punitiva, muito pouco ou nada corretiva, e bem aproveitadora da mão-de-obra indigente. $O$ discurso tem evidentes marcas da eugenia, pois só o labor e a produção têm o dom de salvar e regenerar... O trabalho compulsório ou não caminha lado a lado com a disciplina bem como promete alvissareiras perspectivas para a efetiva constituição da Ordem social! E o microcosmo do cárcere é um evidente exemplo disso.

Realmente, o velho suplício medieval, a masmorra militar, o calabouço, a longínqua colônia penal, a galé e mesmo as "modernas" Casas de Correção estão em franco desuso... Agora apenas transmudados: o novo presídio penitente edita ou reedita de forma dura e "científica" o sistema prisional.

A sociedade moderna passa a discutir minuciosamente a questão do isolamento do detento, muitas vezes ineficaz. Discute, sobretudo, os maltratos físicos e a pena capital; em sua generalidade, bem pouco pragmáticos.

Mas é diferente, bem diferente: o isolamento relativo dos detentos entre si. Contudo permanece ou continua.

O sistema prisional da Pensilvânia teve sua origem na chamada Walnut Street Jail, construída na Filadélfia, Estado da Pensilvânia nos Estados Unidos, em 1792 e foi inspirada, basicamente, na Penitenciária Papal de São Miguel em 1703. Fundamentalmente 
Passagens. Revista Internacional de História Política e Cultura Jurídica,

Rio de Janeiro: vol. 3, no.3, setembro-dezembro 2011, p. 432-464.

ambivalente, possuía esboços de modernidade, bem como de marcante conservadorismo penal: incrivelmente religioso e quaker ${ }^{29}$.

As execuções, a pena de morte, enfim, os humilhantes castigos físicos, a tortura, não podiam mais permanecer. A própria classe dominante americana considerava tais práticas pouco viáveis e nada pragmáticas: teriam que ser abolidas. E abolidas em nome de toda uma lógica - tanto do trabalho, da Ordem e da lei. "Nesta cela fechada, sepulcro provisório, facilmente crescem os mitos da ressurreição, 30 .

Seja como fosse, essa nova arquitetura carcerária, despertava curiosidade até mesmo nos meios europeus. Em princípios do séc. XIX, os franceses Aléxis Clérell de Tocqueville (1805-1859) e Gustave de Beaumont (1802-1865), foram estudar a questão penitenciária nos Estados Unidos da América do Norte, resultando daí um clássico da penalogia: Du système pénitentiaire aux États Unis et de son application en France, tendo a primeira edição sido publicada em 1832.

Esses autores, entre muitas observações e fornecimentos de dados, reconheciam que mesmo nesse país americano, àquela época, existiam, basicamente, dois sistemas presidiários distintos, ou seja, o de Filadélfia (ou Pensilvânico) e o de Auburn. Explicam que as penitenciárias de Sing-Sing, no estado de Nova York, a de Wetherssfield em Connecticut, o presídio de Boston em Massachussets e a penitenciária de Baltimore em Maryland, seguiram o modelo de Auburn. E que mais tarde, no Tennessee, no Maine, o caminho foi o mesmo.

Pelo que puderam informar, nesse pioneiro trabalho - de l'autre coté se trouve la Pensylvanne toute seule (do outro lado se encontra sozinha a Pensilvânia). Segundo Beaumont e Tocqueville, os dois sistemas, ainda que razoavelmente opostos, continham bases comuns. Tudo indicava, pelo menos, que $\mathrm{sim}^{31}$.

\footnotetext{
${ }^{29}$ Facção religiosa oriunda da Igreja Anglicana. Conhecida como Sociedade Religiosa dos Amigos (Religious Society of Friends), teve sua criação em 1652, por ocasião da perseguição religiosa da coroa inglesa. Tinha por prática a rejeição a qualquer organização clerical, em detrimento da pureza moral e da prática ativa do pacifismo, da solidariedade e da filantropia. Fundaram a colônia da Pensilvânia.

${ }^{30}$ Foucault, M. Op. cit.

${ }^{31}$ Catherine Duprat, socióloga francesa, chega a observar que as posições de Tocqueville e Beaumont tendem, por vezes, a se tornar favoráveis ao sistema de Pensilvânia, agitando o chamado grande público!!! Ver: Duprat, Catherine. "Punir et guérir; en 1819, la prison des philanthropes", In: Perrot, Michelle (1980). Impossible prison; recherches sur le système penitentiaire au XIX siècl, Paris: Éditions Seuil, p. 64. Na verdade, a discussão apresentada pelos viajantes franceses é bastante complexa.
} 
Passagens. Revista Internacional de História Política e Cultura Jurídica,

Rio de Janeiro: vol. 3, no.3, setembro-dezembro 2011, p. 432-464.

Inicialmente, por exemplo, o sistema pensilvânico identificava-se perfeitamente com as práticas introduzidas pelos quakers na Filadélfia em 1790 - aproximava as propostas de Mabillon nas suas ideias chaves.

Sua característica principal era o absoluto e mais rígido confinamento celular. Os prisioneiros eram isolados em celas individuais, "surdas" e "mudas": nenhum som era transmitido e ouvido. Não havia trabalho de espécie alguma e como leitura, somente a bíblia. Com tudo isso, até mesmo o escoar do tempo não era do conhecimento do encarcerado ${ }^{32}$. Aliás, os quakers acreditavam firmemente que a prática dos evangelhos era única e suficiente base da educação, e esperavam que a "solitária" tivesse o efeito de trazer o pecador de volta a Deus... A ociosidade era completa.

A cela "pensilvânica" era incrivelmente nua e de poucos metros quadrados. Não havia cama, colchão e mesmo roupa neste catre ou qualquer espécie de móvel e utensílios. A comida era levada à cela somente uma vez por dia e na parte da manhã. $O$ recluso tinha que ficar no mais completo silêncio e sem esboçar qualquer tentativa de comunicação com o mundo exterior: do contrário seria reprimido fisicamente com a vergasta. Um severo guardião rondava e raramente um austero ministro-capelão visitava, quase sempre silenciosamente. Era o que se chamava de Solitary Confinement. $O$ ferrolho que os separava do mundo, Ihes anunciava ao mesmo tempo, que aquela era a sua única habitação.

Este regime levou muitos prisioneiros à loucura e, muitas vezes, por via de consequência, ao suicídio em sua própria cela... Em virtude disso, no seio daquela sociedade, surgiram muitas críticas à religiosidade da "prisão solitária". As próprias autoridades pensilvânicas reconheceram ser necessário alterar esse regime de total e absoluta reclusão e adotaram pequenas modificações. Surgiu o Separaty Confinement: um conjunto de práticas carcerárias que acabou por permitir a comunicação do recluso com visitantes selecionados e considerados de absoluta sanidade moral. Contudo, era vedado o relacionamento de um recluso com outro ou com outros. Além disso, através dessa nova prática "penitente" se reduziam drasticamente os gastos com a vigilância, bem como tal

\footnotetext{
32 O sistema "filadélfico" obedecia a critérios de grande rigidez asséptica: ao chegar à prisão, o condenado era obrigado a tomar banho, tinha os cabelos cortados, a barba feita e um médico examinava-o. Obrigavam-no a vestir um uniforme da instituição, era conduzido até a presença do diretor da penitenciária, quando recebia as instruções relativas a seu comportamento. O moralismo religioso era a norma e a tônica...
} 
Passagens. Revista Internacional de História Política e Cultura Jurídica,

Rio de Janeiro: vol. 3, no.3, setembro-dezembro 2011, p. 432-464.

segregação praticamente anulava, maiores possibilidades de se inaugurar uma estrutura do gênero industrial nas unidades prisionais.

Mas não foi somente por uma questão "humanitária" que a velha e rancorosa prática pensilvânica, gradativamente acabou sendo abandonada. Na verdade, aquela folga celular era frontalmente contrária ao espírito cotidiano "laborioso" burguês, muito especialmente na América do Norte - que passava por substanciosas modificações em sua economia e em seu contexto social. A ideologia do trabalho era uma herança legada pelo "bem comportado" calvinismo europeu e encontrava campo fértil na sociedade americana ${ }^{33}$.

Muitos governadores da poderosa federação consideravam que o sistema carcerário deveria ser mudado: era visivelmente falido e não acompanhava as transformações da Revolução Industrial. E assistia-se uma mão-de-obra ser abandonada e amordaçada, entre quatro paredes, inutilizada até mesmo para os mais "inocentes" fins manufatureiros ou artesanais. Dizia-se que o capitalismo norte americano era viril e extremamente pragmático - queria um proletariado produzindo, não mofando e dando "lamentáveis" prejuízos ${ }^{34}$. Realmente a proposta calvinista começava a se tornar defasada para o próprio sistema ${ }^{35}$.

Não era sem razão que criminólogos reunidos na localidade denominada Auburn (no estado de Nova York e numa velha prisão ali existente), em vista de tudo aquilo que vinha ocorrendo, conseguiram que uma lei (exarada em 1816) determinasse as normas de um (novo) modelo penitenciário, que ficou concluído em 1818. Finalmente o primeiro modelo auburniano terminou de ser construído em 1825 naquela mesma cidade.

\footnotetext{
${ }^{33}$ Até mesmo em Nova Jersey, onde o sistema pensilvânico foi introduzido em 1836, até mesmo aí, o diretor da prisão estatal admitiu como demasiadamente pesado aquele fardo disciplinar (já em franco desuso).

${ }^{34}$ Antes mesmo da penitenciária de Auburn, chegou-se a admitir uma forma carcerária "radial" que foi a grande prisão de Cherry Hill. Aí se esboçava uma prática do trabalho celular, silencioso e absolutamente isolado. Naturalmente era uma "operação" toscamente artesanal que, pela falta de maior envolvimento coletivo, não correspondia a verdadeira demanda produtiva da sociedade americana em fase ou em princípio de expansão. De qualquer forma, o encarcerado não recebia de imediato, tarefas "ocupacionais". Parece que isto era uma calculada tática. Sabe-se que os detentos adivinhando o longo período de total inatividade (e esquecimento), suplicavam o trabalho com desespero...

${ }^{35}$ Como lembrou Vany Leston Pessine Pereira: Em suas ideias fundamentais, “(...) o sistema filadélfico não se encontra totalmente desvinculado das experiências promovidas na Europa a partir do século XVI". Segundo Vany, bem pelo contrário: segue, basicamente, as linhas estabelecidas pelas instituições holandesas $e$ britânicas. Também herdou, acrescenta ela, algumas ideias de Beccaria, Haward e Bentham, bem como os conceitos religiosos aplicados pelo Direito Canônico (Ver: Pereira, Vanny L. P. (2004). [Com] Vivendo na prisão: a sociabilidade na sociedade marginal. Dissertação (Mestrado). Universidade Cândido Mendes, Rio de Janeiro, p. 38).
} 
Passagens. Revista Internacional de História Política e Cultura Jurídica, Rio de Janeiro: vol. 3, no.3, setembro-dezembro 2011, p. 432-464.

As diferenças entre os regimes celulares e punitivos não eram tão grandes assim. Auburn, de qualquer modo, acabou por adotar o trabalho (em completo silêncio ${ }^{36}$ ) durante o dia e o mais rigoroso isolamento celular durante a noite. De qualquer forma, o trabalho em oficinas e, por via de consequência, forçosamente coletivo, apresentava-se como realidade próxima às demandas de um determinado mercado. Pode-se até imaginar que os rigores da comunicação (humana) penitenciária fossem quebrados diante de um quadro como esse. Como observaram Rusche e Kircheimer, não é bom se esquecer, “(...) que uma das razões para a falência do velho sistema de trabalho carcerário em fins do século XVIII era o fato de que o sistema manufatureiro não podia competir com as novas fábrica,37.

Desta forma, constatam esses autores, era necessário instalar maquinaria nas oficinas das prisões - caso existisse a mais remota possibilidade de competir com as empresas de fora... Isso porque a prisão celular tinha dificuldades de escoar sua produção "industrial" 38 .

Mais e mais a nova estratégia carcerária aproximou-se das práticas organizativas de divisão do trabalho exigidas pelo sistema que, antes de tudo, exigia eficiência produtiva no todo social. Auburn, desta forma, passou a ser "adotado" em quase toda a administração penitenciária do país.

O sistema auburniano, por sua estrutura física e arquitetônica, prisional e vigilante, tornou-se o mais difundido no mundo - consistindo quase sempre de: a) um prédio na frente que serve à administração, b) um prédio ou blocos de prédios num segundo plano para servir à segurança e aos órgãos técnico-assistenciais, c) os diferentes blocos celularesprisionais.

Quase sempre todos esses conjuntos são interligados por corredores (ou elevados), um corredor central e corredores perpendiculares. Nos cruzamentos desses corredores, encontram-se "gaiolas" gradeadas, com os portões de passagem comandados por guardas, que se mantêm nesses mesmos cruzamentos. Essas gaiolas no vocabulário comum penitenciário são ou eram chamadas de quadrantes.

\footnotetext{
${ }^{36}$ O silêncio era interpretado como uma necessidade disciplinar - afim de obter do detento não somente a obediência mas a atenção unicamente para a objetividade produtiva. Aí, também, havia a vergasta como prática corretiva...As normas do trabalho não poderiam ser transgredidas. A Ordem não era somente um elemento do conjunto punitivo, estava intimamente integrado ao processo produtivo.

${ }^{37}$ Rusche, G \& Kirchheimer, O. (1999). Op. cit., p.172

38 Ibidem, p. 172.
} 
Passagens. Revista Internacional de História Política e Cultura Jurídica, Rio de Janeiro: vol. 3, no.3, setembro-dezembro 2011, p. 432-464.

Originalmente, as celas foram planejadas para uma carceragem individual, mas que, por razões inerentes à sociedade e ao sistema carcerário, abrigaram bem além do previsto para aquele vigilante espaço.

$\mathrm{Na}$ velha Inglaterra, criara-se em finais do século XVIII, o chamado sistema prisional panóptico. O criador deste sistema foi o inglês Jeremias Bentham (1748-1832), tendo alguma inspiração na figura do filantropo britânico John Howard (1726-1790). A moderna penitenciária tinha aí, seus primeiros germes de existência.

Algumas características podem ser aqui alinhadas para definir esse sistema:

a) previa uma progressão de dois estágios; o primeiro, de grande labor físico durante o dia e isolamento recluso durante a noite, e o segundo, de liberdade transitória a que Bentham chamou de meia liberdade.

b) imprimia (ou pretendia imprimir) a instrução religiosa e a severa educação moral, preocupando-se com a prevenção do crime e a reforma do delinquente.

c) para agilizar o trabalho de sociabilização do criminoso ou considerado como tal, só permitia que este tivesse relacionamento social com pessoas de sã moral - selecionadas na sociedade, para que não houvesse o contágio malsão...

d) mantinha o detento sob vigilância rigorosa e trabalho intenso, quando não extenuante; não permitia que presos mantivessem contato entre eles.

e) para melhor viabilizar esse conjunto prisional, Bentham concebeu um modelo penitenciário de construção arquitetônica rotunda, circular, com celas individuais absolutamente voltadas para o centro vigilante comum - onde se situavam a sala da direção e a torre de vigilância. As celas eram gradeadas na frente e seu interior perfeitamente visível. De tal modo, o conjunto era disposto que a guarda da torre central, visualizaria todo o interior de cada cela de uma só vez. Daí o nome da grande carceragem ser composto de Pan e Ótico, que vem a ser: visualização ampla e total, ao mesmo tempo. Mas o presidiário consegue enxergar apenas parcelas do interior prisioneiro, nunca o seu exterior. No entanto, as práticas panópticas não se limitavam apenas à função prisional da Casa de Inspeção. Segundo Jacques-Alain Miller, o Panóptico não é uma prisão: “(...) é um princípio era de construção, o dispositivo polivalente da vigilância, a máquina óptica universal das construções humanas'39.

\footnotetext{
${ }^{39}$ Bentham, Jeremy (2000). O Panóptico (org. e trad. de Tomaz Tadeu da Silva), Belo Horizonte: Autêntica, nota de contracapa.
} 
Passagens. Revista Internacional de História Política e Cultura Jurídica, Rio de Janeiro: vol. 3, no.3, setembro-dezembro 2011, p. 432-464.

De fato, os mecanismos de vigilância que o inspetor Bentham procurou desenvolver, vão além, bem além. Como observa Michelle Perrot, o panóptico não é apenas um projeto de prisão modelar para a reforma dos diferentes detentos, reintegrados ao circuito da produção ou às fileiras do exército. Segundo esta autora, Bentham pretende que o panóptico seja também um plano exemplar para todas as instituições educacionais, de assistência e de trabalho, uma solução econômica para os problemas do encerramento e, de acordo com a mecânica perfeitamente arranjada de um microcosmo newtoniano, o esboço geométrico de uma sociedade racional ${ }^{40}$ - fantástico pensamento de um homem que nisso parece ter sacrificado sua fortuna e vinte anos de sua maturidade, sonhando ser o demiurgo de um sistema carcerário baseado na atração universal dos interesses, motor da harmonia das leis. O Panóptico não é simplesmente um esboço arquitetônico submetido à escolha dos homens de Estado, mas também uma dessas utopias, como sempre espacializadas, tais como as muitas que se originaram às margens do canal da Mancha entre 1780 e 1840.

Neste sentido, esse livro de Bentham, que foi publicado pela primeira vez em 1787, além de sua atenção voltada às casas penitenciárias, traça toda uma estratégia de controle em relação aos espaços industriais e de trabalho, às casas para pobres, manufaturas, hospícios, lazaretos, hospitais e escolas. Por tudo que foi dito e seguindo esse raciocínio "vigilante", não seria exagero afirmar-se que até mesmo as disposições das ruas, praças e ajardinados de um centro urbanístico tenham chegado a entrar nas cogitações desse pensador ${ }^{41}$. "Os dois princípios fundamentais da construção panóptica são a posição central da vigilância e sua invisibilidade. Cada um se justifica independentemente do outro..."

\section{Um breve resumo estratégico das práticas mais divulgadas do velho jurista londrino com tinturas utilitaristas ou pelo menos, assim ditas e conhecidas.}

Estas estratégias de J. Bentham foram, em boa parte, pacientemente desenvolvidas junto com seu irmão, Samuel. Podemos no que se refere especificamente, ao Panóptico e

\footnotetext{
${ }^{40}$ Perrot, M. (1980). "O inspetor Bentham", Op. cit, p. 109.

${ }^{41}$ No entender de Michel Foucault, resumindo a filosofia prisional da masmorra panóptica - este espaço carcerário (panóptico) fechado, recortado, vigiado absolutamente em todos os pontos, (onde os indivíduos estão inseridos num lugar fixo), os menores movimentos são controlados, onde “(...) todos os acontecimentos são registrados, onde um trabalho ininterrupto de escrita liga o centro e a periferia, onde o poder é exercido sem divisão, segundo uma figura hierárquica contínua, onde cada indivíduo é constantemente localizado, examinado e distribuído entre os vivos, os doentes e os mortos. Isso tudo constitui um modelo compacto do dispositivo disciplinar". (Foucault, M. (1977). Op. cit., p.163).
} 
Passagens. Revista Internacional de História Política e Cultura Jurídica, Rio de Janeiro: vol. 3, no.3, setembro-dezembro 2011, p. 432-464.

toda sua complexa máquina, sublinhar os seguintes pontos ou capítulos: 1) A ideia do princípio da inspeção 2) Plano para uma casa de inspeção penitenciária.

De forma bem geral, no entanto, seja numa perspectiva estritamente prisional, seja noutras formas de vigilância - o projeto de Bentham tinha como principal ou único objetivo, manter muitas pessoas sob grande e eficiente controle. Não importa que estes objetivos fossem até entre eles diferentes e opostos.

Quer se tratasse de punir os incorrigíveis, corrigir os viciados, isolar os suspeitos, pôr para trabalhar os ociosos, socorrer quem necessitasse de ajuda, curar os doentes, instruir em qualquer ramo de atividade quem quisesse aprender ou mesmo guiar a nova estrada da educação... ${ }^{42}$, argumentava Bentham.

\section{Parte III}

\section{Prisões no Brasil: A história de uma longa carceragem (XVI ao XIX)}

A regra é a masmorra...mas-môrra

Antes mesmo do Estado se impor como instrumento organizado, com elementos coercitivos próprios no cotidiano prisional, a classe dirigente tomava suas medidas: na casa do fazendeiro ou na do proprietário urbano; não era incomum a existência do tronco pesado caule, tendo correntes de ferro, onde eram presos os escravos, principalmente à noite. $\mathrm{Na}$ verdade, eram duas compridas peças de madeira sobrepostas com buracos, através dos quais eram passados os punhos ou as pernas e, muitas vezes, os pescoços das vítimas enfileiradas. A hora do trabalho ou do castigo estas peças eram abertas e os escravos eram conduzidos, acorrentados ou não, para fora. Um barracão abrigava, sobretudo à noite, aquele conjunto macabro. Temia-se a fuga.

\section{Outras formas prisionais institucionais: A Cadeia}

Nos tempos coloniais, mas em plena geração de uma rede municipal em expansão, o prédio da Cadeia Pública, juntamente com o Pelourinho, desempenhava a arquitetura da repressão nuclear urbana. A Cadeia era, pelo menos simbolicamente, uma das mais fortes

\footnotetext{
${ }^{42}$ Bentham, J. (2000). Op. Cit.
} 
Passagens. Revista Internacional de História Política e Cultura Jurídica, Rio de Janeiro: vol. 3, no.3, setembro-dezembro 2011, p. 432-464.

imagens do Poder instalado. No Rio de Janeiro, por exemplo, a Cadeia Velha ficava localizada, num casarão na Rua da Misericórdia ${ }^{43}$.

Era um prédio localizado no subsolo do Senado da Câmara e era o bastante para as demandas repressoras da cidade. Mesmo porque, a gerência da Cadeia contava além dela com outras casas onde poderia se socorrer. Poderia citar aqui: o Aljube, o Calabouço, as Presigangas e, mais tarde, a Casa de Correção $^{44}$ e Detenção. Finalmente, surgiram os Presídios.

Mas, apesar das modernidades prisionais exigidas pelos novos tempos, mesmo com elas, a Cadeia Pública não foi eclipsada do mapa urbano. Ela continuou a existir, fazendo parte do cotidiano de um instrumental específico de poder.

Autores como Thomas $\mathrm{H}$. Holloway, acreditam que estabelecimentos políticos criados em tempos joaninos - ou seja, por ocasião da instalação do Estado Português no Rio de Janeiro - significaram grande avanço no que diz respeito aos meios mais ousados e padronizados: numa perspectiva de controlar aqueles, cuja “(...) punição ia além do espancamento sumário nas ruas e das chibatas ordenadas judicialmente,45.

A reforma policial observa o professor Holloway, antecedeu a reforma carcerária em diversas décadas e as prisões da cidade não passavam de masmorras e depósitos onde pessoas eram trancafiadas juntas pelos prazos fixados pelas autoridades.Em princípios do século XIX, como nos demonstra Holloway, a construção da Casa de Correção, em moldes modernos, deu início ao processo de transformação das condições de encarceramento, mas no período de João VI e Pedro I, significava confinamento nas piores condições.

\footnotetext{
43 De maneira geral, na colônia, o preso não era mantido pelo Estado, mas por suas famílias, seus senhores, patrões ou amigos. Quando ainda vigorava, como dominante, a prática da cadeia pública, aqueles que não tinham tais recursos, que tratassem de esmolar para não morrer de fome. Havia correntes que os faziam chegar, por vezes, até o meio da rua, onde ficavam ao sol e à chuva, à espera das almas caridosas que passassem. (ver Edmundo, Luiz (2000). O Rio de Janeiro no tempo dos Vice-Reis; 1763-1808, Brasília: Senado Federal, p. 453-454).

${ }^{44}$ Um estudo detalhado sobre a Casa de Correção, na Corte, foi feita por Amaro Cavalcanti (1849-1922) em seu trabalho "Noticia histórica dos serviços, instituições e estabelecimentos pertencentes a esta repartiçã"o [Ministério da Justiça e Negócios Interiores], editado pela Imprensa Nacional, no Rio de Janeiro em 1898. Trata-se de um relatório oficial.

${ }^{45}$ Holloway, Thomas H. (1997). Polícia no Rio de Janeiro; repressão e resistência numa cidade do século XIX, Rio de Janeiro: Fundação Getúlio Vargas, 344 p, p. 65.
} 
Passagens. Revista Internacional de História Política e Cultura Jurídica, Rio de Janeiro: vol. 3, no.3, setembro-dezembro 2011, p. 432-464.

\section{O Velho Calabouço}

No Rio de Janeiro, o Calabouço ficava ao lado do Morro do Castelo, dando para a baía de Guanabara, não muito longe do Hospital da Santa Casa de Misericórdia. A palavra calabouço significava porão de navio, escuro e úmido. Era o lugar onde os escravos eram "metodicamente" açoitados. Ele fora criado no tempo do vice-rei Luís de Vasconcelos e Souza, primeiramente destinado para os escravos fugidos sentenciados e os condenados à pena de galés. Na década de 1810, essa unidade prisional foi transferida da praia de Santa Luzia, na proximidade do Arsenal de Guerra do Exército para o morro do Castelo ${ }^{46}$.

A historiadora norte-americana Mary C. Karasch chama a atenção que: "(...) a não ser que cometessem crimes e fossem sentenciados por tribunais, os escravos seriam enviados para o Calabouço do Castelo". Parecia ser verdade mesmo: inicialmente o Calabouço abrigava escravos considerados criminosos e até brancos tidos como vagabundos e desertores tinham este fim. Mas acabou que a instituição ficou com a função única de castigar os escravos que fugiam ou cometiam ofensas contra seus donos ${ }^{47}$.

Holloway, no entanto, considerava que o Calabouço era apenas uma das diversas prisões existentes no Rio em 1808 que aproveitavam antigas instalações militares. As construções sólidas nos arredores e morros da cidade, bem como nas ilhas da baia datavam da ocupação dos portugueses desde meados do XVI, tendo como objetivo principal a expulsão dos invasores franceses.

No século XVIII, foram construídas numerosas fortificações, algumas imponentes no lugar dos velhos fortes. Revelam toda uma época: o ouro e mesmo o diamante faziam fortuna, inclusive do Estado. Mas se no período colonial estas "edificações de guerra" faziam algum sentido, em virtude das ameaças externas, no séc. XIX tornaram-se bastante supérfluas - do ponto de vista arquitetural, estritamente militar.

Contudo, aqueles muros, aqueles estratégicos postos de sentinela, bem como as casas de guarda e paióis, tiveram grande utilidade num complexo sistema que seria adaptado para fins prisionais e carcerários.

\footnotetext{
${ }^{46}$ Soares, Carlos Eugênio Líbano (2001). A capoeira escrava, e outras tradições rebeldes no Rio de Janeiro (1808-1850), Campinas: Editora UNICAMP, p. 95.

${ }^{47}$ Karash, Mary C. (2000). A vida dos escravos no Rio de Janeiro; 1808-1850, São Paulo: Companhia das Letras, p.179.
} 
Passagens. Revista Internacional de História Política e Cultura Jurídica, Rio de Janeiro: vol. 3, no.3, setembro-dezembro 2011, p. 432-464.

Os calabouços como que se militarizavam ainda mais; e uma polícia, talvez nova, punha-se a postos.

\section{Algo estava mudando no espaço urbano-social da cidade}

A velha prática do uso de fortalezas militares enquanto prisões já eram conhecidas na história da cidade. E na perspectiva de um aumento da população escrava aquele recurso prisional deixava de ser incomum: as crises políticas só faziam vergar, ao máximo, o arco das tensões cotidianas. O fluxo e o refluxo de uma mão-de-obra servil principalmente no eixo Rio-Minas, só tendia a aprofundar as contradições de classe no contexto global daquele universo.

\section{$O$ recurso do Aljube}

Aljube do árabe al jobbe significava cova profunda, cisterna, cárcere, prisão própria para eclesiásticos. Possivelmente no norte africano, existiam tais prisões, mas no Porto, Portugal, foram conhecidos pelo menos dois Aljubes. O mais antigo estava localizado numa casa contígua ao Arco de Vendoma para o lado da Rua Escura e o segundo levantado a partir de 1749, foi edificado na Rua de Sebastião.

O primitivo Carcel Eclesiástico sobre o qual pouco se sabe, teria sido construído em fins do XVI para o XVII.

Na colônia brasileira, sabe-se que, em janeiro de 1731 “(...) o ouvidor geral do Rio de Janeiro informa na representação do bispo daquela capitania da remissão, que a Câmara daquela Cidade Ihe fez do foro que Ihe pagavam uns chãos que comprou para [0] Aljube que fez à sua custa na mesma cidade"48.

De fato, em 1733, no local situado bem no início da ladeira da Conceição, esquina com a rua da Prainha, o bispo do Rio de Janeiro comprou o terreno, onde seria erigido o futuro cárcere eclesiástico - obtendo isenção de foro municipal.

Até 1808 os bispos somente dominavam nessa prisão onde punham a ferros os padres devassos e malfeitores. Pelo menos, assim considerados.

Variava entre 12 a 20 o número dos que aí se encontravam. Em 1808, chegando a Família Real no Rio, foi reclamada a Cadeia Pública para hospedaria da criadagem da Corte. Os presos civis tiveram de ser transferidos para o Aljube e aí se misturaram aos

\footnotetext{
${ }^{48}$ Arquivo do Conselho Ultramarino Português, v, 26, fl, 181.
} 
Passagens. Revista Internacional de História Política e Cultura Jurídica, Rio de Janeiro: vol. 3, no.3, setembro-dezembro 2011, p. 432-464.

religiosos. Na verdade, os problemas urbanos e sociais começavam a se aprofundar. Uma guerra, muitas vezes surda, minava as antigas bases coloniais escravocratas.

Como as autoridades não queriam prender padres e frades nas prisões civis, juntamente com escravos e outros civis, deixaram os mesmos de ser encarcerados; tendo como consequência praticamente a extinção do foro eclesiástico.

O Aljube tornou-se uma das piores e infectas cadeias públicas, com uma população carcerária assustadora e local, verdadeiramente, epidêmico. Inicialmente, onde havia espaço para 12 ou 20 presos, em 1817, o número chegou a 326 e em 1830 a quase 400. Faleciam muitos, chegavam bem mais. Execuções eram feitas na madrugada ${ }^{49}$.

Em 1831, o Aljube do Rio, tinha uma população, constituída fundamentalmente de escravos e ex-escravos, aproximadamente, calculada em 500 homens. Eram enviados, também para este mesmo destino, revolucionários e "indesejáveis". Um mercado de "carne quase podre, mas ainda forte" dava lucros ao Estado: ali, também, eram vendidos homens e mulheres.

Silencioso ou não, um código de repressão se entranhava no cotidiano e no tecido social da cidade. Essa antiga prisão eclesiástica, depois transformada em imundo espaço prisional, capaz de abrigar a população perigosa e indesejável da cidade, tinha uma estrutura quase conventual.

Não chegavam a dez os aposentos desse lugar sinistro: o ar não era rarefeito, o sol quase não penetrava e durante o dia, o calor era insuportável; a falta de higiene causava apreensão e muitas doenças proliferavam.

Não existiam camas, tampouco catres: escravos e livres dormiam ou dormitavam no chão úmido, cobertos de farrapos.

Com grande frequência inexistia qualquer registro da entrada e da saída dos prisioneiros, bem como do (misterioso) desaparecimento de alguns.

Uma das principais críticas que os reformadores liberais faziam ao antigo sistema legal e judicial-carcerário era a sua arbitrariedade.

Na realidade, na prática, isto significava que o enquadramento do crime, base de toda e qualquer condenação e a sentença ficavam a mercê do magistrado. Contudo, quando o

\footnotetext{
${ }^{49}$ A informação encontra-se em: O COMENTÁRIO, Revista mensal, Rio de Janeiro, série III oㅜ 9 jan 1906, pp. 204-205. Ver, também: LIMA, Hermeto (1875-1947) Revista da Semana Rio de Janeiro, 15 mai 1926. p.31.
} 
Passagens. Revista Internacional de História Política e Cultura Jurídica,

Rio de Janeiro: vol. 3, no.3, setembro-dezembro 2011, p. 432-464.

juiz era o juiz da polícia (isto é, era o chefe de polícia), o caso era decidido por essa instância sob a qual era realizado o ato de prisão.

Qualquer que fosse a razão de uma suposta ameaça à Ordem, geralmente, o réu era lançado aos cárceres do Aljube: escravos, ex-escravos, populares, suspeitos, acusados de roubos, mulheres de má fama e revolucionários eram, particularmente, contemplados com o castigo. Pedro I e José Bonifácio enviaram para lá vários adversários sem declaração de motivo. Muitos foram os presos celebres encarcerados nas masmorras do Aljube. Sem falar de Ratcliff, João da Silva Loureiro e Metrovich, implicados na revolução pernambucana chefiada por Paes de Andrade. Aí esteve o célebre salteador Pedro Espanhol, tido como terror da população carioca (de 1830 a 1834). Não faltavam carrascos voluntários: cenas hediondas se sucediam e o terror passou a ser uma norma do cotidiano prisional.

A comida era escassa ou não havia. Como nas cadeias públicas e nos calabouços, no Aljube o Estado absolutamente pouco se importava e a tarefa passava a ser transferida para "amigos", para irmandades ou mesmo para senhores-escravos, unicamente interessados numa mercadoria humana e de fácil aquisição.

\section{Em tempos de Presigangas}

As prisões militares ao tempo do Brasil português eram, de forma geral, localizadas nos subterrâneos das fortalezas. Eram conhecidas como os calabouços dessas penitenciárias militares.

Até a chegada da Corte Portuguesa (1808) na colônia a Marinha, por exemplo, não possuía prisões próprias ${ }^{50}$. E seus servidores condenados à pena de reclusão cumpriam-na, como os demais militares, nos calabouços de alguma fortaleza ou nas prisões comuns de que eram dotados o espaço colonial.

Finalmente, subordinada à Marinha e ao Inspetor do Arsenal Marítimo foi criada, no Rio de Janeiro, uma penitenciária: na verdade, o primeiro desses estabelecimentos. Mais tarde, surgiram outros em Salvador, Pernambuco, Rio Grande do Sul e Belém do Pará. Igualmente, por volta de 1808, as prisões situadas em fortalezas passaram seus calabouços para a jurisdição da Marinha que passou, por sua vez, a gerenciar tais cárceres no mar e em terra.

\footnotetext{
${ }^{50}$ Greenhalgh, Juvenal (Juvenal Greenhalgh Ferreira Lima) (1998). Presigangas e calabouços ou prisões da Marinha no século XIX, Rio de Janeiro: Serviço de Documentação da Marinha, p. 9.
} 
Passagens. Revista Internacional de História Política e Cultura Jurídica,

Rio de Janeiro: vol. 3, no.3, setembro-dezembro 2011, p. 432-464.

Paloma Siqueira Fonseca depois de se referir ao historiador naval Greehalgh (18901966), explica que presiganga "(...) é uma corruptela do inglês press-gang, destacamento naval comandado por um oficial e encarregado de recrutar homens para servirem na Marinha de Guerra Inglesa" ${ }^{51}$.

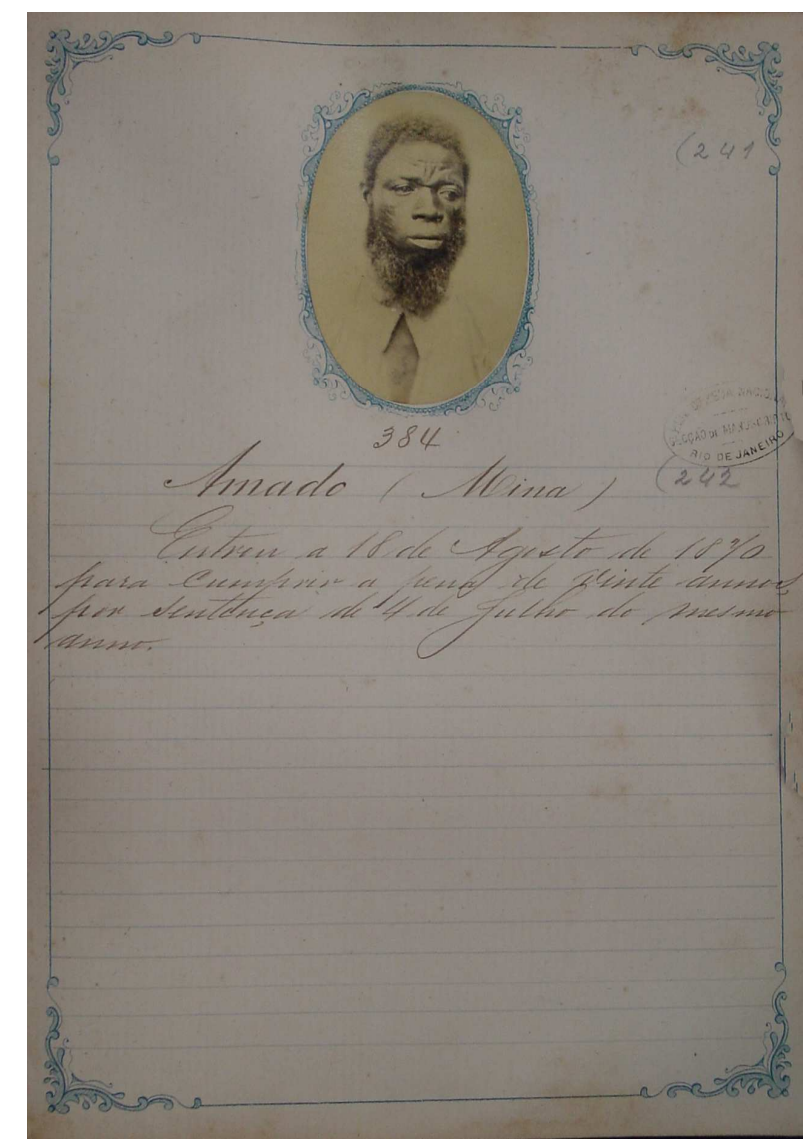

Galeria dos Condenados. Sessão de Iconografia (BNRJ)

Como assinala esta historiadora, o estudo da presiganga serve como via de acesso a práticas como o recrutamento forçado.

Sendo assim, a embarcação, geralmente em avançado estado de decadência, articulava num mesmo espaço, um modelo de punição e uma cultura marítima próprios da sociedade e do entorno geográfico em que se situava.

Paloma Fonseca chama a atenção que entre as classes de navios, a presiganga era uma nau de guerra da Armada portuguesa, geralmente avariada e em decorrência disso transformada em prisão no Brasil. Isto ficou claro quando da transferência da Corte para a

\footnotetext{
${ }^{51}$ Fonseca, Paloma Siqueira. "A presiganga e as punições da Marinha (1808-1831)", In: Castro, Celso (org.) (2004). Nova história militar brasileira, Rio de Janeiro: Fundação Getúlio Vargas, p. 139.
} 
Passagens. Revista Internacional de História Política e Cultura Jurídica, Rio de Janeiro: vol. 3, no.3, setembro-dezembro 2011, p. 432-464.

colônia brasileira. Fundeada na baía da Guanabara, ao norte da ilha das Cobras, a presiganga foi um (sinistro) depósito de galés, forçados, degredados, recrutas, prisioneiros de guerra, infratores militares e escravos. Também para ali iam revolucionários, como Cipriano Barata (1762-1838) que escreveu um documento sobre a presiganga da baía da Guanabara.

Em fins de 1830 e em princípios de 1831, diversas levas de imigrantes alemães, aguardando condução para seus destinos nas colônias do sul, foram hospedados na embarcação presiganga. Enfim, este depósito-prisão de horror era mais um poderoso instrumento de controle do Estado sobre a população mais desprezada, constituída de escravos, fugitivos, suspeitos, revolucionários e imigrantes.

Uma boa avaliação sobre esta prisão é a de autoria do historiador e pesquisador Carlos Eugênio Líbano Soares em "A capoeira escrava, e outras tradições rebeldes no Rio de Janeiro (1808-1850) ${ }^{\text {52 }}$. O assunto foi tratado também no excelente estudo de Marco Morel, "Cipriano Barata na sentinela da liberdade,53.

\section{O surgimento da Casa de Correção e da Casa de Detenção}

Em 1831, talvez em nome de uma racionalidade e de um pragmatismo de ocasião, a Regência Provisória cogitou de construir uma Casa de Correção - sem dúvida, forma de carceragem mais sofisticada. Efetivamente, 19 anos mais tarde o novo templo "ocupacional" - prisional já fazia parte da paisagem da Corte brasileira e, em seguida (ou pouco tempo depois), criar-se a Casa de Detenção - cuja função era a de "selecionar" os "moradores" daquele campo carcerário. Realmente, ambas integravam o complexo penitenciário.

A Casa de Correção - numa perspectiva "moderna" - fazia às vezes do "arquejante" Aljube e mesmo dos calabouços tradicionais, seguindo um plano arquitetural traçado com vistas a novas formas de controle e de incentivo ao labor. Planejada tendo como base 0 modelo norte-americano de Auburn, de confinamento celular parcial, isto é, celas individuais à noite e trabalho coletivo durante 0 dia ${ }^{54}$.

\footnotetext{
${ }^{52}$ Libânio, C. E. (2001). Op. cit, p. 95-99.

53 Morel, Marco (2001). Cipriano Barata na sentinela da liberdade, Salvador: Academia de Letras da Bahia/Assembleia Legislativa do Estado da Bahia.

${ }^{54}$ No entender do jurista Evaristo de Moraes (1871-1939), a exposição da planta da Casa de Correção foi orientada pelos desenhos e reflexões produzidas, em 1826, pela Sociedade Inglesa para melhoramentos das prisões. Segundo Evaristo, os organizadores da planta tinham em mente construir uma prisão pelo sistema panóptico. Isto significaria a existência de raios convergentes para um ponto central, com o objetivo de controle
} 
Passagens. Revista Internacional de História Política e Cultura Jurídica, Rio de Janeiro: vol. 3, no.3, setembro-dezembro 2011, p. 432-464.

Ficava claro que o trabalho diurno grupal era destinado para os condenados à prisão com trabalhos forçados. A Correção originalmente previa, aproximadamente, duzentos prisioneiros em celas (quase sempre) individuais e oficinas coletivas de carpintaria, metalurgia, etc. ${ }^{55}$.

Em fins da década de 1850, no Rio de Janeiro, assistiu-se o apagar das luzes das últimas e velhas masmorras militares, por fim fechadas. Foi o caso, por exemplo, do Forte de Santa Cruz, situado na entrada da baía de Guanabara, bem em frente à cidade do Rio de Janeiro.

Os oitenta prisioneiros, até então, condenados a pesadas penas, foram transferidos para a ala especial, recém-inaugurada da Casa de Correção.

O açoitamento público não precisou de sua teatralidade habitual: as bem guarnecidas e eficientes muralhas da Casa cumpriam seu convincente pape ${ }^{56}$.

Em 1826, quando havia, cerca, de 50 mil escravos na Corte do Rio, os senhores enviaram quase 1.800 deles para as prisões do Estado, com o objetivo correcional ainda que, as velhas punições continuassem a existir. Mas o importante era o controle: ali estavam embutidos os primeiros passos de um aprendizado-hierárquico.

Convêm notar que os africanos eram punidos com mais rudeza e mais freqüência do que os brasileiros. Representariam os primeiros, contudo, um perigo social maior do que os segundos?

A Casa de Correção era, formalmente, um presídio com funções laborativas, punitivas, rigorosamente prisionais e proclamadamente correcionais (ou assim entendidas). Enquanto que, a Casa de Detenção funcionava, burocraticamente, como instrumento selecionador, um verdadeiro funil: capaz de fornecer dados técnicos do "criminoso"; sempre postos à disposição da grande repressão correcional. Por isso mesmo, o espaço geográfico das duas instituições era absolutamente o mesmo.

e vigilância (Moraes, Evaristo de (1923). Prisões e instituições penitenciárias no Brasil, Rio de Janeiro: Editora Candido de Oliveira).

${ }^{55}$ Numa nota do diretor da Casa de Correção, dirigida ao ministro Nabuco de Araújo, entre 1864 e 1866, assim se refere o major Daniel J. Thompson: "A direção da Casa não se limita hoje somente à Penitenciária, tem ela mais a seu cargo os presos da prisão e os galés, sob a denominação de prisão civil, o instituto de menores artesãos, a inspecção das obras, a administração do calabouço e o depósito de africanos livre"s. Ver IHGB Arquivo.

${ }^{56} \mathrm{E}$ embora o velho castigo não tenha, absolutamente, desaparecido, sua intensidade foi notada. Mas havia, ainda, o Calabouço da Casa de Correção que consistia de duas espaçosas salas, comportando, aproximadamente, 300 homens e mulheres: os primeiros nos pisos superiores. Na verdade, este Calabouço era parte integrante da grande Correção. 


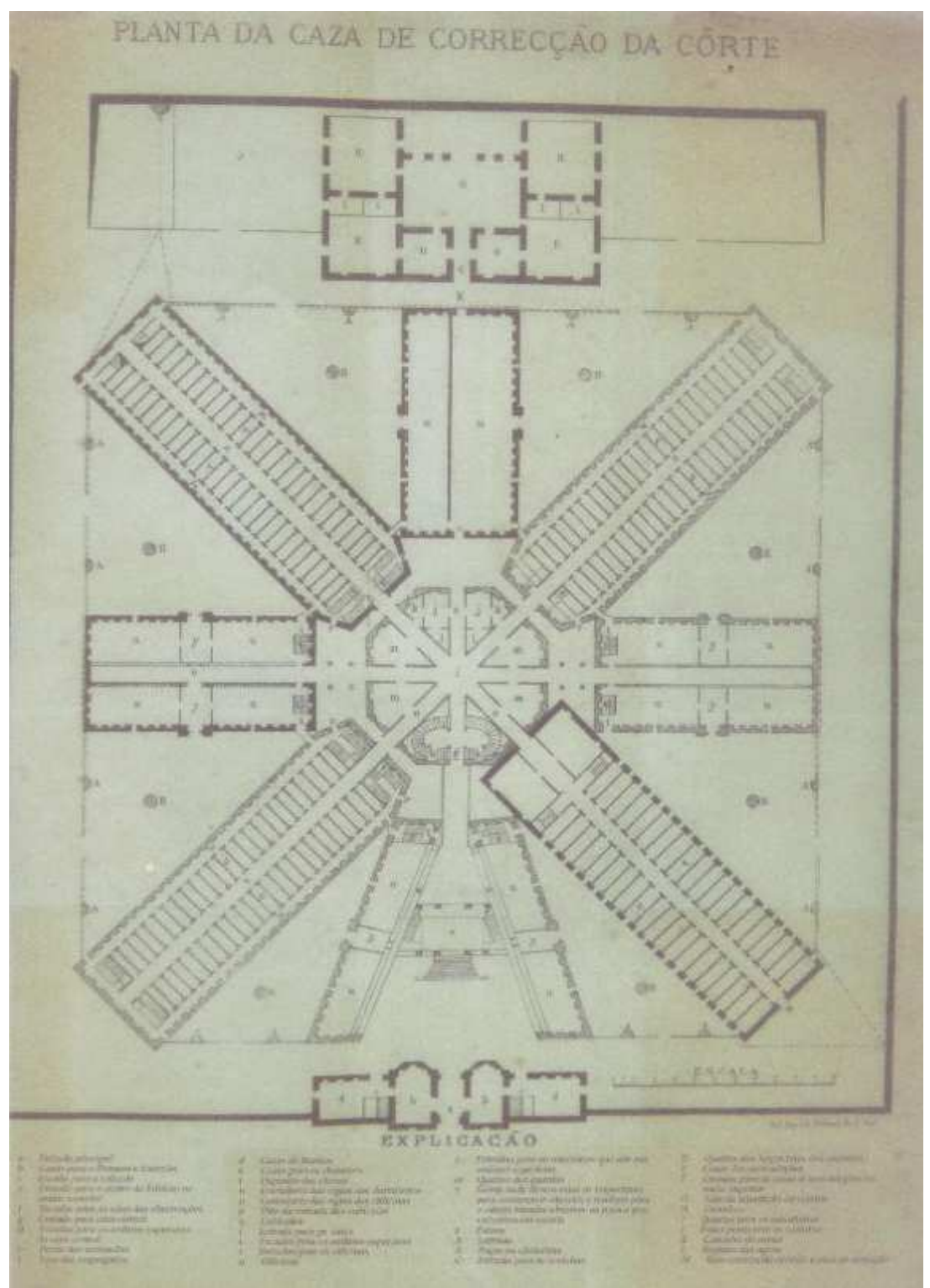

Original do acervo da Biblioteca do IHGB.

Como lembrou Carlos Eugênio Líbano Soares, o plano da Detenção era idêntico ao da Casa da Correção: um grande prédio em forma de cruz, tendo no centro o ponto nervoso de controle da circulação e nos corredores com inúmeras celas individuais. Tudo lembrava a clássica concepção britânica do panóptico.

$\mathrm{Na}$ ocasião, o todo poderoso ministro da Justiça, senador vitalício e conselheiro de Estado, José T. Nabuco de Araújo (1813-1878) se dava conta da importância nodal dessas penitenciárias, ainda em faze embrionária. Antes de Nabuco e Araújo, o ministro Euzébio de 
Passagens. Revista Internacional de História Política e Cultura Jurídica, Rio de Janeiro: vol. 3, no.3, setembro-dezembro 2011, p. 432-464.

Queiroz (1812-1868) era mais "prudente" com a questão: chegava a temer a experiência de Auburn, preferia o silêncio alienado, conservador e religioso do espaço pensilvânico.

Isto parece claro na década de 1860, sob a clara influência conservadora de Queiroz:

Num "severo" regulamento para a Casa de Correção da Corte de julho de 1864, o major diretor do estabelecimento, Daniel José Thompson, alinha ou esboça alguns pontos: Titulo $1^{\circ}$ (Da Casa de Correção da Corte)

Artigo $1^{\circ}$ - A Casa de Correção e o edifício destinado nesta Corte a execução da pena com ou sem trabalho dentro do respectivo recinto tem por dependências: o Instituto de Menores Artesãos; o depósito de Africanos livres; uma seção de Bombeiros; a prisão civil anexa à Penitenciária; as obras e a prisão do Calabouço enquanto o Governo Imperial não fizer a desmembração conveniente.

No artigo $2^{\circ}$, do titulo $2^{\circ}$, referente aos condenados à prisão com trabalho: "Os condenados à prisão com trabalho continuarão a estarem sujeitos à classificação, disciplina, trabalho, penas disciplinares, a terem o vestuário, alimentação economia interna, curativo, parte dos produtos, ensino moral e religioso (como se acha decretado e regulado em 6 de agosto de $1850)^{57}$.

\section{Um regulamento vigilante, apenas rascunhado}

A questão da vigilância sistemática nos serviços cotidianos da Casa de Correção teria que ganhar, pelo menos, um projeto. Afinal, tratava-se da Casa de Correção da Corte centro político do Império:

Um projeto foi inicialmente rascunhado e regulado para os Guardas da Correção da Corte, tendo como seu autor o diretor e major Daniel José Thompson. Alguns artigos valem a reprodução e mesmo serem comentados.

O artigo $1^{\circ}$ fala que a guarda da Casa de Correção da Corte, iria compreender todo o pessoal preciso para a vigilância dos presos e guarda do Estabelecimento, sob as ordens imediatas do Diretor e na ausência deste - do vedor, únicos de quem receberiam as ordens.

$\mathrm{O}$ artigo $2^{\circ}$ estabelece as funções das duas Guardas. A $1^{\underline{a}}$ denominada Guarda interna e a $2^{a}$ externa, tendo cada uma delas o seu chefe que se denominaram Guardas Mandantes.

57 IHGB-Arquivo. Regulamento para a Casa de Correção da Corte, julho de 1864. 
Passagens. Revista Internacional de História Política e Cultura Jurídica, Rio de Janeiro: vol. 3, no.3, setembro-dezembro 2011, p. 432-464.

O artigo 3ํㅡㄹ diz o documento, estabelece a 1a Seção que além da Guarda Mandante terá tantos guardas quanto forem precisos para o serviço, computando-se o seu número na razão de 2 para 25 condenados, incluídos neste número tanto os penitenciários como os de prisão simples e galés. Existiam, ainda 4 guardas para o serviço da Portaria.

Ao longo dos demais artigos, sente-se uma preocupação com a harmonia e a Ordem, a prisão, bem como, o abuso de um lado e de outro, o respeito do preso, ou seja, de sua conduta, as formas imoderadas (é vedado à Guarda o uso de palavras imoderadas que pudessem exacerbar o ânimo dos presos); a contínua, absoluta e permanente vigilância.

Os artigos $, 8,10,11$ e mesmo 16 , responsabilizam a Guarda pelo asseio no serviço e dentro do estabelecimento prisional. As rondas noturnas ou diárias devem ser atentamente acompanhadas pela Guarda. Os Guardas têm por dever acompanhar diariamente os presos nos trabalhos, vigiando-os constantemente. Quanto aos Guardas só poderão ser admitidas pessoas morigeradas e que não tenham sofrido penas infamantes: sendo preferidos os Nacionais e preferencialmente aqueles que tenham servido no Exército e na Armada ${ }^{58}$.

Com a própria ampliação do sistema repressivo em função da organização das chamadas classes perigosas, da elevada sucessão das arruaças, uma outra "arquitetura" prisional começava a se edificar, talvez a se esboçar.

As prisões situadas na Corte do Império Brasileiro, na década de 1880, chegavam, às vezes, a concentrar até mais de 10.000 detentos. A Cadeia Pública, por exemplo, perdeu praticamente toda sua função, o Aljube perdera inteiramente a sua, assim como a velha Presiganga $^{59}$. A repressão triplicava suas forças.

Mas o velho "Calabouço" foi fechado em 1875, o sistema judicial modernizava-se, como observou Holloway ${ }^{60}$. A Casa de Correção ${ }^{61}$ centralizava ou reunia o elenco mais

\footnotetext{
58 IHGB -Arquivo. Projeto de regulamento para os Guardas da Casa de Correção da Corte - Rascunho, Rio de Janeiro, $s / d$ ).

${ }^{59}$ A partir do ano de 1870, quando muitos milhares de escravos ou ex-escravos voltavam dos campos da morte paraguaios (muitas centenas deles na ilusão de encontrarem uma liberdade que não houve), uma surda guerra se armou. As tinturas de um falso liberalismo procuravam ocultar o germe racista da classe dominante brasileira.

${ }^{60}$ Holloway, T. H. (1997). Op. cit., p.231.

${ }^{61}$ A historiadora Icléia Thiesen num estudo sobre as diferentes formas de controle das autoridades prisionais do Império, depois de apresentar - como pano de fundo - o cotidiano disciplinar e de trabalho "regenerador" da população carcerária, destaca os novos e modernos mecanismos introduzidos pelas autoridades do Estado escravocrata brasileiro. A autora faz especial menção à fotografia como instrumento para esses fins: " $A$ imagem fotográfica reforça os elementos negativos dos apenados, tornando-os indesejáveis e passíveis de rejeição e exclusão. Imprimem um documento-verdade, atingindo, pelo imaginário, a memória social
} 
Passagens. Revista Internacional de História Política e Cultura Jurídica,

Rio de Janeiro: vol. 3, no.3, setembro-dezembro 2011, p. 432-464.

completo de práticas repressivas e prisionais do Estado Monárquico, Imperial: chegava-se mesmo a uma sofisticação eugênica.

Tudo indicava que o estabelecimento era direcionado pelas normas organizativas de Auburn: havia trabalho nas oficinas montadas da Casa de Correção como parte da rotina de punição de acordo com aquele sistema.

Considerável número de prisioneiros condenados à antiga pena de galés eram escravos e as obras públicas eram quase sempre o destino dos mesmos. O Ministério da Justiça, já em 1878, chamou a atenção para a "anomalia" pela qual essa punição aplicada aos escravos é totalmente ineficaz, isto é, não produz o efeito de intimidação.

Sendo assim, o escravo condenado a galés muda de residência, mas não muda de condição. E o trabalho forçado? Ele já o sofre em sua vida anterior.

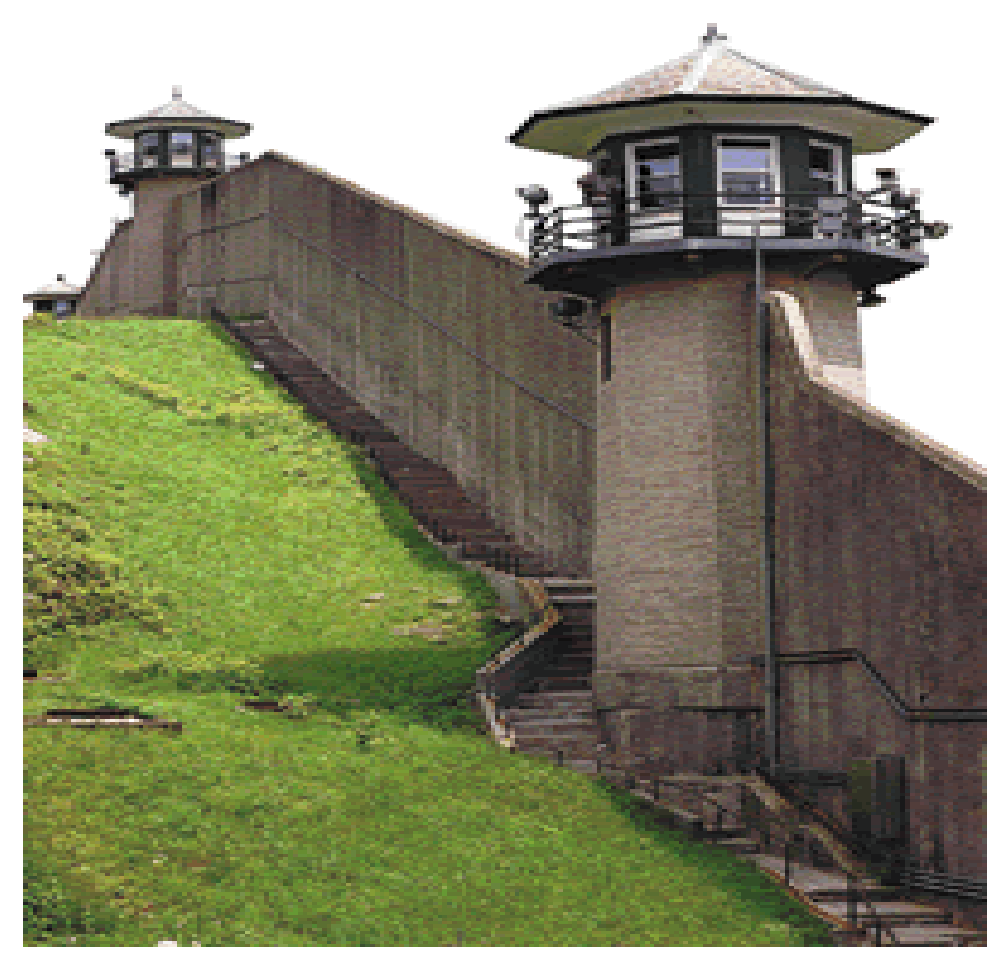

\section{Referências Bibliográficas}

transmitida em imagens". (Thiesen, I. "A Casa de Correção da Corte e a Fotografia Identificatória, 1859-1876" (2006), In Revista do Instituto Histórico e Geográfico Brasileiro, Rio de Janeiro, 167(430), 194-195, jan-mar). 
Passagens. Revista Internacional de História Política e Cultura Jurídica, Rio de Janeiro: vol. 3, no.3, setembro-dezembro 2011, p. 432-464.

Batista, Nilo, Zaffaroni, R., Alagia, Alejandro e Stokar, Alejandro (2003). Direito penal brasileiro-I, 2 ed., Rio de Janeiro: Editora Revan.

Bauman, Z. (1999). Globalização, as consequências humanas, Rio de Janeiro: J. Zahar.

Bentham, J. (1974). Uma introdução aos princípios da moral e da legislação, São Paulo: Abril Cultural.

Bentham, Jeremy (2000). O Panóptico (org. e trad. de Tomaz Tadeu da Silva), Belo Horizonte: Autêntica.

Duby, George (1990). Senhores e camponeses, São Paulo: Martins Fontes.

Duprat, Catherine. "Punir et guérir; en 1819, la prison des philanthropes", In: Perrot, Michelle (1980). Impossible prison; recherches sur le système penitentiaire au XIX siècl, Paris: Éditions Seuil.

Edmundo, Luiz (2000). O Rio de Janeiro no tempo dos Vice-Reis; 1763-1808, Brasília: Senado Federal.

Ferreira, Vieira (1948). "O degredo nas ordenações do Reino e os degredados vindos com Pedro Álvares Cabral”, In Revista do Instituto Histórico e Geográfico Brasileiro, v. 200, julset. (Apud Vainfas Ronaldo, p. 181).

Fonseca, Paloma Siqueira. "A presiganga e as punições da Marinha (1808-1831)", In: Castro, Celso (org.) (2004). Nova história militar brasileira,Rio de Janeiro: Fundação Getúlio Vargas.

Foucault, Michel (1985). Microfísica do poder, 5 ed, Rio de Janeiro: Graal.

Foucault, Michel. (1983). Vigiar e punir, nascimento da prisão, 2a․ Edição, Petrópolis: Vozes.

Greenhalgh, Juvenal (Juvenal Greenhalgh Ferreira Lima) (1998). Presigangas e calabouços ou prisões da Marinha no século XIX, Rio de Janeiro: Serviço de Documentação da Marinha.

Holloway, Thomas H. (1997). Polícia no Rio de Janeiro; repressão e resistência numa cidade do século XIX, Rio de Janeiro: Fundação Getúlio Vargas.

Karash, Mary C. (2000). A vida dos escravos no Rio de Janeiro; 1808-1850, São Paulo: Companhia das Letras.

Melossi, Dario e Pavarinni, Massimo (2006). Cárcere e fábrica: as origens do sistema penitenciário; séculos XVI - XIX, Rio de Janeiro: Revan, ICC.

Miller, Jacques-Alain. "A máquina panóptica de Jeremy Bentham", In: Bentham, J. (2000). 0 Panóptico, Belo Horizonte: Autêntica. 
Passagens. Revista Internacional de História Política e Cultura Jurídica, Rio de Janeiro: vol. 3, no.3, setembro-dezembro 2011, p. 432-464.

Moraes, Evaristo de (1923). Prisões e instituições penitenciárias no Brasil, Rio de Janeiro: Editora Candido de Oliveira.

Morel, Marco (2001). Cipriano Barata na sentinela da liberdade, Salvador: Academia de Letras da Bahia/Assembleia Legislativa do Estado da Bahia.

Neder, Gizlene (2000). Iluminismo juídico-penal luso-brasileiro: obediência e submissão, Rio de Janeiro: Freitas Bastos/ICC.

Pereira, Vanny L. P. (2004). [Com] Vivendo na prisão: a sociabilidade na sociedade marginal. Dissertação (Mestrado). Universidade Cândido Mendes, Rio de Janeiro.

Rusche, G e Kirchheimer, O. (1999). Punição e estrutura social Rio de Janeiro: Freitas Bastos.

Soares, Carlos Eugênio Líbano (2001). A capoeira escrava, e outras tradições rebeldes no Rio de Janeiro (1808-1850), Campinas: Editora UNICAMP.

Thiesen, I. "A Casa de Correção da Corte e a Fotografia Identificatória, 1859-1876" (2006), In Revista do Instituto Histórico e Geográfico Brasileiro, Rio de Janeiro, 167(430), 194-195, jan-mar).

Thompson, A. (2001). A questão penitenciária, 5 ed, Rio de Janeiro: Forense.

Vainfas, Ronaldo (org) (2000). Dicionário do Brasil colonial (1500-1805), Rio de Janeiro: Objetiva.

Valette, Jacques. "Le bagne de Rochefort, 1815-1852", In Perrot, Michelle (1980). L'Impossible Prison; recherches sur le système pénitentiaire au XIX siècle. Paris: Seuil..

Zaffaroni, E. Raúl (2007). O inimigo no Direito Penal, Rio de Janeiro: Revan.

Recebido para publicação em dezembro de 2010. 